Tropical Journal of Pharmaceutical Research October 2018; 17 (10): 2013-2017

ISSN: $1596-5996$ (print); 1596-9827 (electronic)

(C) Pharmacotherapy Group, Faculty of Pharmacy, University of Benin, Benin City, 300001 Nigeria.

Available online at http://www.tjpr.org

Original Research Article

http://dx.doi.org/10.4314/tjpr.v17i10.17

\title{
Protective effect of liquiritin on corticosterone-induced neurotoxicity in PC12 cells
}

\author{
Jing $\mathrm{Wu}^{1 *}$, Fei Xiang Huang ${ }^{2}$, Jing Wang ${ }^{3}$, Chang Cheng Shi ${ }^{4}$, Guo Ying Fang ${ }^{1}$ \\ ${ }^{1}$ Department of Pharmacy, ${ }^{2}$ Department of Traditional Chinese Medicine, ${ }^{3}$ Department of Obstetrics, Hangzhou Obstetrics \& \\ Gynecology Hospital, Hangzhou, Zhejiang 310008, ${ }^{4}$ Department of Pharmacy, Hangzhou First People's Hospital, Hangzhou, \\ Zhejiang 310006, PR China
}

*For correspondence: Email: wujing1_work@126.com; Tel: +86-0571-56005734

Sent for review: 29 May 2018

Revised accepted: 23 September 2018

\begin{abstract}
Purpose: To determine the protective effects of liquiritin on corticosterone-induced neurotoxicity in rat pheochromocytoma (PC12) cells.

Methods: Neurotoxicity in PC12 cells was induced by different concentrations of corticosterone. Proliferation of PC12 cells was evaluated using CCK8 assay kits, while apoptosis was determined by flow cytometry.

Results: The results indicate that corticosterone inhibited the proliferation of PC12 cells time- and dosedependently. The inhibitory effect $(0.2 \mathrm{mM})$ was ameliorated by liquiritin. Furthermore, the cell apoptosis rate and protein level of caspase 3 in PC12 cells induced by corticosterone were ameliorated by liquiritin (1 and $2 \mathrm{mg} / \mathrm{mL}$ ) treatment. Moreover, the protective effect of liquiritin (2 $\mathrm{mg} / \mathrm{mL}$ ) on corticosterone induced neurotoxicity in PC12 cells was weakened by K252a (the specific TrkB inhibitor) treatment. In addition, the protein level of brain-derived neurotrophic factor (BDNF) and (tyrosine-kinase receptor) TrkB showed a reverse trend to caspase 3.

Conclusion: Liquiritin shows protective effects against neurotoxicity induced by corticosterone in PC12 cells, and these effects are exerted via up-regulating BDNF/TrkB signaling.
\end{abstract}

Keywords: Liquiritin, Antidepressant, Corticosterone, Neuroprotection, PC12 cells, BDNF/TrkB signaling

\begin{abstract}
This is an Open Access article that uses a funding model which does not charge readers or their institutions for access and distributed under the terms of the Creative Commons Attribution License (http://creativecommons.org/licenses/by/4.0) and the Budapest Open Access Initiative (http://www.budapestopenaccessinitiative.org/read), which permit unrestricted use, distribution, and reproduction in any medium, provided the original work is properly credited.

Tropical Journal of Pharmaceutical Research is indexed by Science Citation Index (SciSearch), Scopus, International Pharmaceutical Abstract, Chemical Abstracts, Embase, Index Copernicus, EBSCO, African Index Medicus, JournalSeek, Journal Citation Reports/Science Edition, Directory of Open Access Journals (DOAJ), African Journal Online, Bioline International, Open-J-Gate and Pharmacy Abstracts
\end{abstract}

\section{INTRODUCTION}

Depression is a debilitating, life-threatening and frequently occurring psychiatric disorder. In addition to emotional abnormalities, most patients with depression suffer from organic damage to the nervous and mental system [1]. In recent years, a great number of studies have reported that corticosterone at high levels could induce depressive-like behavior in rats, which can be improved by acupuncture and antidepressant treatment [2,3]. Moreover, corticosterone induce changes in brain anatomy and neurochemistry, both of which are closely associated with depression [4]. Brainderived neurotrophic factor (BDNF) is one kind of major neurotrophic factors in adult brain. A large number of studies show that BDNF expression 
were reduced in depressed patients or rodents after corticosterone treatment [4,5]. Meanwhile, the expression of BDNF were up-regulated by classical antidepressantsin depressed patients and rats brain [6]. This means that BDNF is an important target of the classical antidepressants.

Pheochromocytoma (PC12) cell is the most commonly used neuronal cell lines for neuroscience research [7]. Previous study indicated that corticosterone at high concentration induces cell injury and cell death in pheochromocytoma PC12 cells and hippocampal neurons, and these neurotoxicity caused by corticosterone were ameliorated by classical antidepressants [8]. These reports indicate that antidepressants possesses neuroprotective and neurotrophic activities in PC12 cells. Liquiritin is the main content extracted from Glycyrrhiza Radix, and it has been reported to possess anticancer and anti-inflammatory abilities [9,10]. Liquiritin also showed antidepressant-like effects in the tail suspension test and forced swimming test in mice [10]. Whereas, the specific molecular mechanism is not yet clear. Thus, this study has tested the neuroprotective effects of liquiritin on corticosterone-induced neurotoxicity in vitro, and investigated the involvement of BDNF signaling pathway in this process.

\section{EXPERIMENTAL}

\section{Chemicals and reagents}

Corticosterone and liquiritin were obtained from the Aladdin company (Shanghai, China). CCK-8 and Annexin V-FITC apoptosis detection kits were purchased from Beyotime Biotechnology (Shanghai, China). The primary antibodies of BDNF, TrkB and Caspase 3 were purchased from Abcam (MA, USA). The primary antibody of GAPDH was purchased from CST (MA, USA).

\section{Effects of corticosterone on the proliferation of PC12 cells}

PC12 cell line was offered by Shanghai Institute of Biochemistry and Cell Biology (SIBCB, Shanghai, China). This study was approved by the Ethics Committee of the hospital. PC12 cells were treated with corticosterone $(0,0.2,0.4$ and $0.8 \mathrm{mM}$ ) for $72 \mathrm{~h}$. The proliferation of PC12 cells sing determined by CCK-8 assay kit at 0, 24, 48 and $72 \mathrm{~h}$ after treatment.

\section{Effect of different concentrations of liquiritin on proliferation of corticosterone treated PC12 cells}

PC12 cells were seeded into 96-well culture plate
( $2 \times 10^{4}$ cells per well), and cultured with corticosterone $(0.2 \mathrm{mM})$ at $37^{\circ} \mathrm{C}$ for $48 \mathrm{~h}$. Then, liquiritin $(0,0.25,0.5,1,2$ and $4 \mathrm{mg} / \mathrm{mL}$, in dimethyl sulfoxide, DMSO) was added. Those cells were cultured for $72 \mathrm{~h}$ at normal condition, and the proliferation of PC12 cells was measured using CCK-8 assay kit at 0, 24, 48 and $72 \mathrm{~h}$ after treatment.

\section{Evaluation of protective effects of liquiritin}

PC12 cells were divided into 5 groups: control group, corticosterone $(0.2 \mathrm{mM})$ treatment group, corticosterone $(0.2 \mathrm{mM})+$ liquiritin $(1 \mathrm{mg} / \mathrm{mL})$ group, corticosterone $(0.2 \mathrm{mM})+$ liquiritin (2 $\mathrm{mg} / \mathrm{mL})$ group, corticosterone $(0.2 \mathrm{mM})$ + liquiritin $(2 \mathrm{mg} / \mathrm{mL})$ group and corticosterone $(0.2$ $\mathrm{mM})+$ liquiritin $(2 \mathrm{mg} / \mathrm{mL})+\mathrm{K} 252 \mathrm{a}(10 \mathrm{nM})$ ( the BDNF/TrkB signaling inhibitor [11]) group.

The cells in the latter four groups were cultured with corticosterone $(0.2 \mathrm{mM})$ at normal condition. Then, the cells were cultured with corresponding drugs for another $48 \mathrm{~h}$. Cell samples were harvested at the end. The cell apoptosis rate was detected by flow cytometry using Annexin V-FITC/PI apoptosis detection kit. Moreover, proteins levels of BDNF, TrkB and caspase3 were tested by Western blotting.

\section{Cell proliferation and apoptosis}

PC12 cells were seeded in 96-well culture plates at a concentration of $2 \times 10^{4}$ per well. Then, the cell proliferation of PC12 cells in were determined using CCK-8assay kit according to the manufacturer's instructions. The PC12 cells apoptosis was determined using FITC-labelled annexin-V/PI assay kit. Cells in each group $(1 \times$ $10^{6}$ ) were cultured with FITC-labelled annexin-V and $\mathrm{PI}$ for $20 \mathrm{~min}$ at $25{ }^{\circ} \mathrm{C}$. The intensity of $\mathrm{PI}$ or annexin- $V$ fluorescence was determined by FACScan (Becton-Dickinson, CA, USA); 10,000 cells were assessed in each sample.

\section{Western blotting assay}

The protein expressions of BDNF, TrkB and caspase 3 were measured by western blotting.

The total protein was extracted from PC12 cells, separated by SDS-PAGE, then transferred onto the PVDF membranes. After incubation with the primary antibody at $4{ }^{\circ} \mathrm{C}$ for $15 \mathrm{~h}$, the membranes were further incubated with a secondary antibody at $4{ }^{\circ} \mathrm{C}$ for $2 \mathrm{~h}$. Protein bands were determined using an ECL-detecting kit (Beyotime Biothech, Shanghai, China); GAPDH protein served as loading control. 


\section{Statistical analysis}

Data are expressed as mean \pm standard deviation. The statistical analysis was performed by Student's t-test and ANOVA using SPSS 20.0 software (IBM, Armonk, NY, USA). $P<0.05$ was considered statistically significant.

\section{RESULTS}

\section{Effect of corticosterone on proliferation of} PC12 cells

The proliferation of $\mathrm{PC} 12$ cells was measured at 0, 24, 48 and $72 \mathrm{~h}$ after treatment using CCK-8 assay kit. As shown in Figure 1, the proliferation of PC12 cells was time and dose-dependently decreased by corticosterone treatment. In addition, corticosterone, at a low dose $(0.2 \mathrm{mM})$, inhibited the proliferation of PC12 cells. Thus, this concentration was used in subsequent experiments.

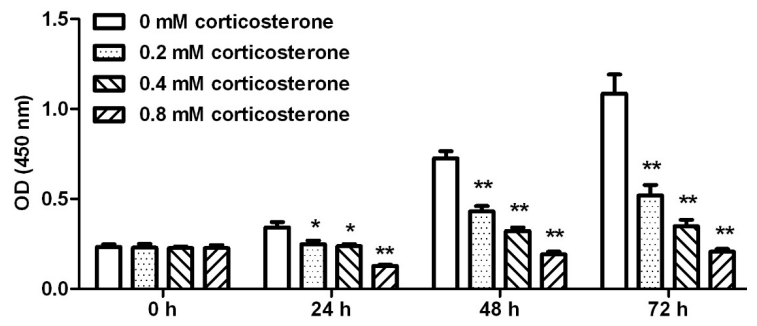

Figure 1: Effects of corticosterone on the proliferation of PC12 cells (testing by CCK-8 assay); $p<0.05$ and $p<0.01$, compared with $0 \mathrm{mM}$ corticosterone group

\section{Effect of concentration of liquiritin on proliferation of corticosterone-treated PC12 cells}

The proliferation of $\mathrm{PC} 12$ cells was unchanged by liquiritin at lower concentrations in a short time (Figure 2). However, at longer treatment times and doses, the proliferation of corticosterone treated PC12 cells was increased by liquiritin ( 2 and $4 \mathrm{mg} / \mathrm{mL})$ after 48 and $72 \mathrm{~h}(1,2$ and 4 $\mathrm{mg} / \mathrm{mL}$ ) of incubation (Figure 2).

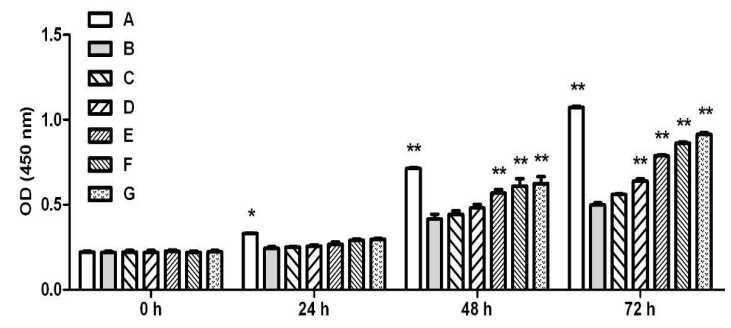

Figure 2: Effect of different concentration of liquiritin on the proliferation of corticosterone treated PC12 cells. A: control group, B: corticosterone $(0.2 \mathrm{mM})+$ liquiritin $(0 \mathrm{mM})$ group, C: corticosterone $(0.2 \mathrm{mM})+$ liquiritin $(0.25 \mathrm{mM})$ group, $\mathrm{D}$ : corticosterone $(0.2 \mathrm{mM})$ + liquiritin $(0.5 \mathrm{mg} / \mathrm{mL})$ group, $\mathrm{E}$ : corticosterone $(0.2$ $\mathrm{mM})+$ liquiritin $(1 \mathrm{mg} / \mathrm{mL})$ group, $\mathrm{F}$ : corticosterone $(0.2$ $\mathrm{mM})+$ liquiritin (2 $\mathrm{mg} / \mathrm{mL})$ group, G: corticosterone $(0.2 \mathrm{mM})+$ liquiritin $(4 \mathrm{mg} / \mathrm{mL})$ group; $p<0.05$ and $p$ $<0.01$, compared with group $B$

\section{Protective effects of liquiritin against corticosterone-induced neurotoxicity}

To clarify the involvement of BDNF in the process of neuroprotection, BDNF/TrkB signaling inhibitor, K252a, was used [11]. The apoptosis rate in each group was measured by flow cytometry and proteins levels of BDNF, TrkB and the pro-apoptotic cleaved form caspase3 [12] were tested by western blotting.

The results indicate the cell apoptosis rate as well as the protein expression of caspase 3 were increased by corticosterone-induced neurotoxicity in PC12 cells, and the increased effects were ameliorated by liquiritin ( 1 and 2 $\mathrm{mg} / \mathrm{mL}$ ) at $48 \mathrm{~h}$ after treatment (Figure 3 and Figure 4). Whereas, this protective effect of liquiritin $(2 \mathrm{mg} / \mathrm{mL})$ was abated by $\mathrm{K} 252 \mathrm{a}$ treatment. In addition, the proteins level of BDNF and TrkB in PC12 cells were negative correlation with the expression ofcaspase 3 .
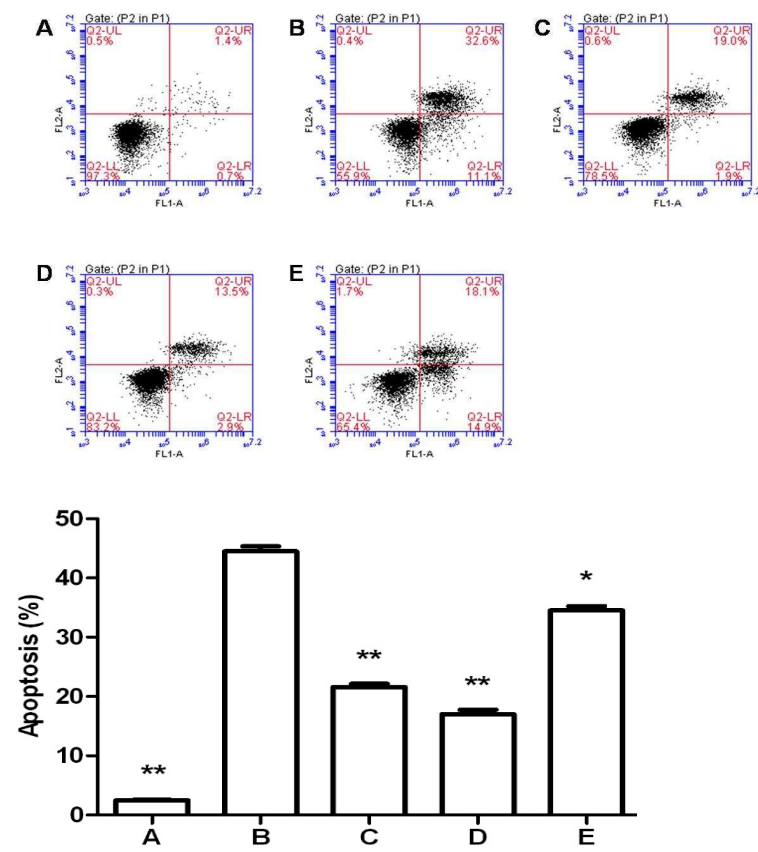

Figure 3: Liquiritin protected against corticosteroneinduced increased cell death in PC12 cells. A: control group, B: corticosterone $(0.2 \mathrm{mM})$ treatment group, $\mathrm{C}$ : corticosterone $(0.2 \mathrm{mM})+$ liquiritin $(1 \mathrm{mg} / \mathrm{mL})$ group, $\mathrm{D}$ : corticosterone $(0.2 \mathrm{mM})+$ liquiritin $(2 \mathrm{mg} / \mathrm{mL})$ group, E: corticosterone $(0.2 \mathrm{mM})+$ liquiritin $(2 \mathrm{mg} / \mathrm{mL})$ $+\mathrm{K} 252 \mathrm{a}(10 \mathrm{nM})$ group; $p<0.05$ and $p<0.01$, compared with group $B$ 


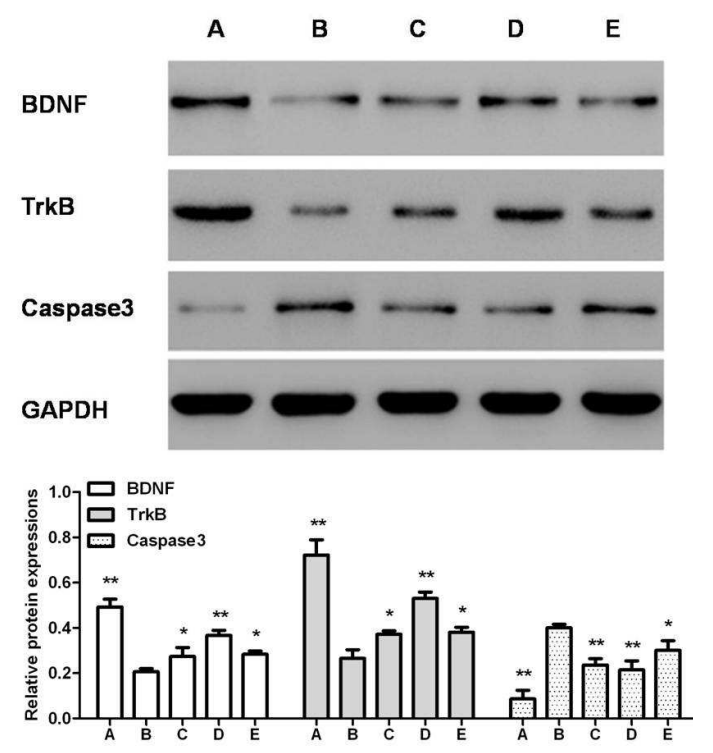

Figure 4: Effect of liquiritin on the protein expression of BDNF, trkB and caspase 3 in PC12 cells. A: control group, B: corticosterone $(0.2 \mathrm{mM})$ treatment group, $\mathrm{C}$ : corticosterone $(0.2 \mathrm{mM})+$ liquiritin $(1 \mathrm{mg} / \mathrm{mL})$ group, $\mathrm{D}$ : corticosterone $(0.2 \mathrm{mM})+$ liquiritin $(2 \mathrm{mg} / \mathrm{mL})$ group, E: corticosterone $(0.2 \mathrm{mM})+$ liquiritin $(2 \mathrm{mg} / \mathrm{mL})$ + K252a (10 nM) group; $p<0.05$ and ${ }^{* *} p<0.01$, compared with group $B$

\section{DISCUSSION}

Depression is one of mental disorders characterized by decreased interest and pleasure and lowered mood. More serious is that the morbidity will increase, if there is no remedy, according to WHO's prediction [13]. PC12 cell line is the most commonly used neuronal cell lines for neuroscience research in vitro studies $[7,14]$. Liquiritin is the main content extracted from Glycyrrhiza Radix, and it has been reported to possess a variety of biological activities $[9,10]$. In the present study, liquiritin showed protective effects on corticosterone-induced neurotoxicity in PC12 cells via up-regulation of BDNF/TrkB signaling.

In recent years, a neurotrophic hypothesis has been used to explain the mechanisms of antidepressant drugs and the pathophysiology of depression. According to this hypothesis, the vulnerability to stress-induced depression is as a result of changes in expression levels of trophic factors in neurons which are innervated by monoaminergic projections [15]. Furthermore, BDNF hypothesis postulates that stress decrease the expression of BDNF and this could be reversed by anti-depression therapy $[16,17]$. In particular, BDNF is a member of the neurotrophin family which promotes neuronal viability in adulthood [18]. The functions of BDNF are modulated by the activation of intracellular signaling pathways upon high affinity binding to the trkB receptor $[19,20]$. The present results indicate that the protein expressions of BDNF and trkB were down-regulated in corticosterone treated PC12 cells. This symptom was ameliorated by liquiritin ( 1 and $2 \mathrm{mg} / \mathrm{mL}$ ).

Thus, liquiritin treatment protects against corticosterone-induced decreased cell proliferation and increased cell death in PC12 cells. Liquiritin also shows antidepressant-like effects on corticosterone-induced neurotoxicity in PC12 cells and the possible mechanism of which involves the up-regulation of BDNF/trkB signaling. Therefore liquiritin is a potential therapeutic drug for depression.

\section{DECLARATIONS}

\section{Acknowledgement}

This work was funded by Zhejiang Science and Technology Program of Traditional Chinese Medicine (nos. 2015ZB093), Hangzhou City Health Science and Technology Plan Project (nos. 2016A58), Hospital Pharmacy Special Research Project of Zhejiang Pharmacy (nos. 2014ZYY19) and Health Science and Technology Program of Hangzhou Obstetrics \& Gynecology Hospital (nos. 2015YJB05 and 2017YJA03).

\section{Conflict of interest}

No conflict of interest is associated with this work.

\section{Contribution of authors}

We declare that this work was done by the authors named in this article and all liabilities pertaining to claims relating to the content of this article will be borne by the authors.

\section{REFERENCES}

1. Mcallisterwilliams RH, Ferrier IN, Young AH. Mood and neuropsychological function in depression: the role of corticosteroids and serotonin. Psychol Med 1998; 28: 573-584.

2. Crupi R, Mazzon E, Marino A, La SG, Bramanti $P$, Cuzzocrea $S$, Spina E. Melatonin treatment mimics the antidepressant action in chronic corticosterone-treated mice. J Pineal Res 2010; 49: 123-129.

3. Lee B, Shim I, Lee HJ, Yang Y, Hahm DH. Effects of acupuncture on chronic corticosterone-induced depression-like behavior and expression of 
neuropeptide $Y$ in the rats. Neurosci Lett 2009; 453 : 151-156.

4. Schaaf MJ, De Kloet ER, Vreugdenhil E. Corticosterone effects on BDNF expression in the hippocampus. Implications for memory formation. Stress 2000; 3: 201 . 208.

5. Karege F, Perret G, Bondolfi G, Schwald M, Bertschy G, Aubry JM. Decreased serum brain-derived neurotrophic factor levels in major depressed patients. Psychiatry Res 2002; 109: 143-148.

6. Shimizu E, Hashimoto K, Okamura N, Koike K, Komatsu $N$, Kumakiri C, Nakazato M, Watanabe $H$, Shinoda $N$, Okada S. Alterations of serum levels of brain-derived neurotrophic factor (BDNF) in depressed patients with or without antidepressants. Biol Psychiatry 2003; 54: 7075.

7. Li ZY, Guo Z, Liu YM, Liu XM, Chang Q, Liao YH, Pan $R L$. Neuroprotective effects of total saikosaponins of Bupleurum yinchowense on corticosterone-induced apoptosis in PC12 cells. J Ethnopharmacol 2013; 148 : 794-803.

8. Zhu MY, Wang WP, Bissette G. Neuroprotective effects of agmatine against cell damage caused by glucocorticoids in cultured rat hippocampal neurons. Neuroscience 2006; 141: 2019-2027.

9. Dong S, Inoue A, Zhu Y, Tanji M, Kiyama R. Activation of rapid signaling pathways and the subsequent transcriptional regulation for the proliferation of breast cancer MCF-7 cells by the treatment with an extract of Glycyrrhiza glabra root. Food Chem Toxicol 2007; 45: 2470.

10. Wang W, Hu X, Zhao Z, Liu P, Hu Y, Zhou J, Zhou D, Wang Z, Guo D, Guo H. Antidepressant-like effects of liquiritin and isoliquiritin from Glycyrrhiza uralensis in the forced swimming test and tail suspension test in mice. Prog Neuropsychopharmacol Biol Psychiatry 2008; 32 : 1179-1184.
11. Perez-Pinera $P$, Hernandez $T$, García-Suárez $O$, Carlos $F D$, Germana A, Valle MD, Astudillo A, Vega JA. The Trk tyrosine kinase inhibitor K252a regulates growth of lung adenocarcinomas. Mol Cell Biochem 2007; 295: 19-26.

12. Zheng TS, Schlosser SF, Dao T, Hingorani R, Crispe IN, Boyer JL, Flavell RA. Caspase-3 controls both cytoplasmic and nuclear events associated with Fasmediated apoptosis in vivo. Proc Natl Acad Sci U S A 1998; 95: 13618-13623.

13. The global burden of disease: 2004 update. World Health Organization 2008.

14. Mao QQ, Huang Z, Ip SP, Xian YF, Che CT. Protective Effects of Piperine Against Corticosterone-Induced Neurotoxicity in PC12 Cells. Cell Mol Neurobiol 2012; 32: 531-537.

15. Nestler EJ, Gould E, Manji H, Buncan M, Duman RS, Greshenfeld HK, Hen R, Koester S, Lederhendler I, Meaney M. Preclinical models: status of basic research in depression. Biol Psychiatry 2002; 52: 503-528.

16. Burke TF, Advani T, Adachi M, Monteggia LM, Hensler JG. Sensitivity of hippocampal 5-HT1A receptors to mild stress in BDNF-deficient mice. Int $J$ Neuropsychopharmacol 2013; 16: 631-645.

17. Alboni S, Benatti C, Capone G, Corsini D, Caggia F, Tascedda F, Mendlewicz J, Brunello N. Time-dependent effects of escitalopram on brain derived neurotrophic factor (BDNF) and neuroplasticity related targets in the central nervous system of rats. Eur J Pharmacol 2010; 643: 180.

18. Ibáñez CF. Neurotrophic factors: from structure-function studies to designing effective therapeutics. Trends Biotechnol 1995; 13: 217-227.

19. Binder DK, Scharfman HE. Brain-derived Neurotrophic Factor. Growth Factors 2004; 22: 123-131.

20. Reichardt LF. Neurotrophin-regulated signalling pathways. Philos Trans $R$ Soc Lond B Biol Sci 2006; 361: 1545-1564. 